\title{
PERLINDUNGAN HUKUM TERHADAP PEMBELI TANAH BERSERTIFIKAT GANDA DENGAN CARA ITIKAD BAIK DEMI KEPASTIAN HUKUM
}

\author{
Iwan Permadi \\ Fakultas Hukum Universitas Brawijaya \\ Email : permadi_iwan@yahoo.com
}

\begin{abstract}
The certificate issued for the beneficiary, intended it can be easily proved the land tenure, the ongoing disputes of land tenure even thought land registration has been done. Many people's with good faith in the practice of land transaction in Indonesia were deceived because the land have two or more certificates. Double certificates can be caused due of intent, not accidental and wrong administrative, both internal or external. A dispute settlement of land tenure (double certificates) trought by National Land Agency (BPN ) and litigation (court).
\end{abstract}

Keywords : Legal Protection, Double Sertificate, Good Faith

\begin{abstract}
Abstrak
Penerbitan sertifikat diberikan kepada yang berhak, bertujuan agar pemegang hak dapat dengan mudah membuktikan kepemilikan tanahnya, dalam pelaksanaannya walaupun pendaftaran tanah sudah dilakukan, namun masih sering terjadi sengketasengketa hak-hak atas tanah. Banyak orang dengan itikad baik dalam praktek jual beli tanah di Indonesia yang tertipu karena tanah yang dibelinya mempunyai dua atau lebih sertifikat. Penyebab terjadinya sertifikat ganda bisa dikarenakan adanya unsur kesengajaan, ketidaksengajaan dan dikarenakan kesalahan administrasi baik secara internal maupun eksternal. Mekanisme penanganan sengketa hak atas tanah (sertifikat ganda) penyelesaiannya dapat melalui Instansi Badan Pertanahan Nasioanl (BPN) dan melalui pengadilan.
\end{abstract}

Kata Kunci : Perlindungan Hukum, Sertifikat Ganda, Itikad Baik

\section{A. Pendahuluan}

Persoalan tentang pertanahan seringkali menimbulkan konflik yang berkepanjangan antara orang dengan orang maupun orang dengan badan hukum. Sengketa tentang tanah ini seolah tidak ada habis-habisnya dan selalu terjadi di dunia ini karena kebutuhan manusia akan tanah selalu bertambah seiring pertambahan penduduk. Di Indonesia, jumlah penduduk di Indonesia pada tahun 2015 sudah mencapai 252.370.792 jiwa dan semuanya memerlukan tanah yang digunakan sebagai tempat tinggal maupun untuk bercocok tanam (www.bps.go.id).

Di Indonesia, ada beberapa pokok permasalahan tentang tanah yang dapat menimbulkan sengketa, yaitu :

1. Tanah yang mempunyai sertifikat ganda; 
2. Konflik penguasaan dan pemilikan tanah-tanah Negara;

3. Konflik tentang pemilikan karena waris;

4. Konflik tentang tanah yang belum disertifikatkan yaitu status haknya masih tanah adat dan masih tanah dengan dilekati hak barat;

5. Proses pendaftaran hak dari prona;

6. Penguasaan dan okupasi tanah dari bekas hak guna usaha yang sudah berakhir dan tidak diperpanjang;

7. Dan masih banyak yang lainnya.

Permasalahan tersebut semakin lama ternyata semakin banyak yang belum diselesaikan, hal ini dikarenakan kurangnya pemahaman para penegak hukum terhadap substansi perundang-undangan agrarian dan adanya beberapa peraturan perundang-undangan yang bersifat sektoral, misalnya antara Undang-Undang Nomor 41 tahun 1999 ternyata substansinya berbeda dengan Undang-Undang Nomor 2 tahun 2012 tentang Pengadaan Tanah dalam hal menentukan diperbolehkannya tanah negara yang berstatus sebagai tanah hutan untuk digunakan dalam program pengadaan tanah untuk kepentingan pembangunan.

Di samping persoalan-persoalan tersebut diatas, dalam praktek jual beli tanah di Indonesia, masih banyak orang dengan itikad baik yang tertipu dalam jual beli tanah yang ternyata tanahnya mempunyai dua sertifikat bahkan mempunyai empat sertifikat sekaligus. Tentunya hal ini sangat merugikan karena dapat menyebabkan kepastian hukum yang semakin tidak pasti oleh karena dia membeli dengan itikad baik dan akan merugikan iklim investasi apabila yang membeli tanah itu adalah seorang investor yang ingin membuat pabrik atau tempat usaha. Contoh-contoh kasus yang terjadi, yaitu :

1. Munculnya sertifikat ganda akibat dari prona di ponorogo seperti yang diberitakan di Koran tempo tanggal 14 Mei 2005;

2. Pengadilan Tata Usaha Negara dalam putusan perkara Nomor : 03/G.TUN/2007/PTUN-Dps tentang penyelesaian sengketa sertifikat ganda/overlapping

3. Putusan No. 10/G/Tun/2002/Ptun. Semarang di Kelurahan Tandang Kecamatan tembalang Kota Semarang.

Kasus-kasus munculnya sertifikat ganda tersebut tentunya membuat masyarakat khawatir kalau membeli tanah ternyata sertifikatnya dobel atau ganda. Persoalan ini menjadi menarik apabila dikaitkan dengan itikad baik seseorang secara hukum yang diatur dalam pasal 1338 ayat (3) Kitab Undang-Undang Hukum Perdata (KUHPerdata). Maksud itikad baik disini adalah bertindak sebagai pribadi yang baik. Itikad baik dalam pengertian yang 
sangat subjektif dapat diartikan sebagai kejujuran seseorang, yaitu yang terletak pada seseorang pada waktu diadakan perbuatan hukum sedangkan itikad baik dalam pengertian obyektif yaitu bahwa pelaksanaan suatu perjanjian itu harus didasarkan pada norma kepatutan atau sesuatu yang dirasa sesuai dengan yang patut dalam masyarakat.

Dalam konteks penelitian ini, seseorang dengan itikad baik yang membeli tanah dan tidak mengetahui ada sertifikat ganda terhadap tanah yang dibelinya tentunya harus mendapatkan perlindungan hukum. Hal ini sangat dimungkinkan karena asas itikad baik ini sudah diatur dalam perundang-undangan yaitu dalam Kitab Undang-Undang Hukum Perdata (KUHPerdata). Tetapi dalam kenyataannya, pembeli dengan itikad baik ini seringkali kalah atau tidak mendapatkan hak atas tanah yang dibelinya tersebut karena dianggap dia tidak berhati-hati dan sebagainya.

Pengertian penguasaan dalam hukum tanah di Indonesia, dikenal penguasaan yuridis yang dilandasi hak yang dilindungi oleh hukum dan umumnya memberi kewenangan kepada pemegang hak untuk menguasai secara fisik tanah yang dihaki. Ada juga pengertian penguasaan yuridis yang tidak memberi kewenangan untuk menguasai tanah yang bersangkutan secara fisik (Boedi Harsono, 2003 : 23).

Dalam doctrin common law system, konsep penguasaan atau pemilikan tanah diartikan bahwa pemilik tanah dapat menguasai sebanyak mungkin ruang yang ada dan menggunakan apa yang ada di dalam tanah yang dikuasai tersebut. Hal tersebut diungkapkan oleh Peter Butt, yaitu the common law doctrine that ownership of land extends to the periphery of the universe and that the owner of the surface owns (as much of the space above the ground as he can occupy or use in connection with the land) (Peter Butt, 1996, 15).

Dalam Undang-Undang Nomor 5 Tahun 1960 tentang Peraturan Dasar PokokPokok Agraria (UUPA) diatur dan sekaligus ditetapkan hirarki hak-hak penguasaan atas tanah, yaitu :

1. Hak Bangsa Indonesia yang disebut dalam pasal 1 sebagai hak penguasaan atas tanah yang tertinggi, beraspek perdata dan publik.

2. Hak Menguasai Negara yang disebut dalam pasal 2 yang beraspek publik.

3. Hak Ulayat Masyarakat Hukum Adat yang disebut dalam pasal 3 yang beraspek perdata dan publik.

4. Hak-Hak Perorangan/Individual, semuanya beraspek perdata terdiri atas :

a. Hak-hak Atas Tanah sebagai hak-hak individual yang semuanya secara langsung ataupun tidak langsung bersumber pada hak bangsa yang disebut dalam pasal 16 dan 53 UUPA. 
b. Wakaf, yaitu hak milik yang sudah diwakafkan pasal 49 .

c. Hak jaminan atas tanah yang disebut "hak Tanggungan" dalam pasal 25, 33, 39 dan 51 UUPA.

Di samping hirarki hak penguasaan di atas, Arie Sukanti menyatakan bahwa UUPA membedakan hak penguasaan tanah menjadi dua kelompok, yaitu hak atas tanah dan hak jaminan atas tanah (Arie Sukanti Hutagalung, 1985: 34).

Pada prinsipnya hak penguasaan atas tanah berisikan wewenang, kewajiban dan/atau larangan bagi pemegang haknya untuk berbuat sesuatu mengenai tanah yang dihaki. Sesuatu yang boleh, wajib atau dilarang untuk diperbuat, yang merupakan isi hak penguasaan itulah yang menjadi kriteria atau pembeda di antara hak-hak penguasaan atas tanah yang diatur dalam hukum agraria.

Berdasarkan konsep Hak Menguasai Negara, Negara dapat menentukan macammacam hak atas sumber-sumber agraria, yang dapat diberikan kepada dan dipunyai oleh orang-orang, baik sendiri maupun bersama-sama dengan orang lain serta badan-badan hukum (Andik Hardiyanto, 1998: 40).

Setelah terjadi unifikasi hukum tanah, maka di Indonesia hak atas tanah diatur dalam Undang-Undang Pokok Agraria. Secara tegas hak atas tanah ini diatur dalam pasal 16 ayat (1), yaitu “ Hak atas tanah sebagai dimaksud dalam pasal 4 ayat (1) ialah :
a. Hak milik,
b. Hak guna usaha,
c. Hak guna bangunan,
d. Hak pakai,
e. Sewa,
f. Hak membuka tanah,
g. Hak-hak lain yang tidak termasuk dalam hak-hak tersebut di atas yang akan ditetapkan dengan undang-undang serta hak-hak yang sifatnya sementara sebagai yang disebutkan dalam pasal 53".

Menurut pasal 53 ayat (1) UUPA, yaitu "hak-hak yang sifatnya sementara sebagai yang dimaksud dalam pasal 16 ayat (1) huruf $h$, ialah hak gadai, hak usaha bagi hasil, hak menumpang dan hak sewa atas tanah pertanian diatur untuk membatasi sifat-sifatnya yang bertentangan dengan undang-undang ini dan hak-hak tersebut diusahakan hapusnya di dalam waktu yang singkat".

Menurut Pasal 16 ayat (2) UUPA, yaitu " hak-hak atas air dan ruang angkasa sebagai dimaksud pasal 4 ayat (3) ialah : 

a. Hak guna air;
b. Hak pemeliharan dan penangkapan ikan;
c. Hak guna ruang angkasa

Di samping itu, dalam tatanan konsep hak atas tanah dalam hukum nasional Indonesia, ada beberapa hal yang tergolong bersifat Privat atau perorangan yaitu :

1. Hak-Hak Perorangan Yang Individual. Sebagaimana dalam lingkungan Hak Ulayat, dalam lingkup Hak Bangsapun dimungkinkan para warganegara Indonesia, sebagai pihak yang mempunyai hak-bersama atas tanah-bersama tersebut, masing-masing menguasai dan menggunakan sebagian dari tanah-bersama itu secara individual, dengan hak-hak yang bersifat pribadi. Menguasai dan menggunakan tanah secara individual berarti bahwa tanah yang bersangkutan boleh dikuasai secara perorangan. Tidak ada keharusan menguasainya bersama-sama dengan orang-orang lain secara kolektif, biarpun menguasai dan menggunakan tanah secara bersama dimungkinkan dan diperbolehkan. Hal itu di tegaskan dalam poasal 4 ayat 1 yang menyatakan bahwa : Atas dasar hak Menguasai dari Negara sebagai yang dimaksud dalam Pasal 2, ditentukan adanya macam-macam hak atas permukaan bumi, yang disebut tanah yang dapat diberikan kepada dan dipunyai oleh orang-orang, baik sendiri maupun bersamasama dengan orang-orang lain serta badan-badan hukum.

2. Hak-Hak Atas Tanah Yang Bersifat Pribadi. Sifat pribadi hak-hak individual menunjuk kepada kewenangan pemegang hak untuk menggunakan tanah yang bersangkutan bagi kepentingan dan dalam memenuhi kebutuhan pribadi dan keluarganya. Hal ini ditegaskan dalam pasal 9 ayat 2 UUPA, yang menyatakan, bahwa: Tiap-tiap warganegara Indonesia baik laki-laki maupun wanita mempunyai kesempatan yang sama untuk memperoleh sesuatu hak atas tanah serta untuk mendapat manfaat dan hasilnya, baik bagi diri sendiri maupun keluarganya. Kata-kata untuk mendapat manfaat dan hasilnya, baik bagi diri sendiri maupun keluarganya menunjukkan sifat pribadi dari hak-hak atas tanah dalam konsepsi Hukum Tanah Nasional.

3. Hak-Hak Atas Tanah Mengandung Unsur Kebersamaan. Hak-hak atas tanah yang individual yang bersifat pribadi tersebut dalam konsepsi Hukum Tanah Nasonal mengandung unsur kebersamaan. Unsur kebersamaan atau unsur kemasyarakatan tersebut ada pada tiap hak atas tanah, karena semua hak atas tanah secara langsung ataupu tidak langsung bersumber pada Hak Bangsa, yang merupakan hak-bersama 
dan tanah yang dihaki secara individual itu adalah sebagian dari tanah-bersama. Hakhak atas tanah yang langsung bersumber pada Hak Bangsa adalah apa yang disebut hak-hak primer, yaitu Hak Milik, Hak Guna Usaha, Hak Guna Bangunan, Hak Pakai yang diberiakan oleh negara, sebagai Petugas Bangsa. Hak-hak yang bersumber tidak langsung dari Hak Bangsa, adalah apa yang disebut hak-hak sekunder, yaitu hak-hak yang diberikan oleh pemegang hak primer, seperti hak sewa, bagi hasil, gadai dan lain-lainnya. Sifat pribadi hak-hak tanah yang sekaligus mengandung unsur kebersamaan atau kemasyarakatan tersebut, dalam pasal 6 UUPA yaitu semua hak atas tanah mempunyai fungsi sosial.

Dalam konteks keilmuan, Hukum Agraria sesudah berlakunya UUPA melahirkan hak atas tanah. Hak atas tanah dalam UUPA tersebut dapat diberikan kepada dan dipunyai oleh orang baik itu sendiri atau secara bersama-sama dan atau badan hukum. Hak-hak atas tanah tersebut di atas tidak akan bermakna jika penggunaannya terbatas hanya pada tanah sebagai permukaanya bumi saja. Untuk keperluan apa pun pasti diperlukan juga penggunaan sebagai tubuh bumi yang ada dibawahnya dan air di atasnya. Dalam Pasal 15 UUPA disebutkan bahwa : memelihara tanah, termasuk menambah kesuburannya serta mencegah kerusakannya adalah kewajiban tiap-tiap orang, badan hukum atau instansi yang mempunyai hubungan hukum dengan tanah itu, dengan memperhatikan pihak yang ekonomis lemah. Mengingat hak atas tanah pada salah satu sisi memberi suatu kewenangan tertentu kepada pemegang haknya dan disisi lain mewajibkan pihak lain untuk menghormati hak-hak tersebut, maka perlu adanya pembatasan kewenangan pemegang hak tersebut. Adapun pembatasan itu secara umum antara lain :

a. Penggunaan hak atas tanah tidak boleh menimbulkan kerugian pada pihak lain ;

b. Penggunaan hak atas tanah harus sesuai dengan isi dan sifat hak itu sendiri;

c. Penggunaan hak atas tanah harus sesuai dengan ketentuan rencana tata ruang atau tata guna tanah;

d. Penggunaan hak atas tanah tidak boleh untuk praktik-praktik pemerasan;

e. Tidak diperbolehkan menggunakan ruang atas tanah dan ruang bawah tanah yang tidak berkaitan langsung dengan penggunaan tanah atau permukaan bumi.

Dalam ketentuan Pasal 19 UUPA disebutkan bahwa: "Untuk menjamin kepastian hukum oleh Pemerintah diadakan pendaftaran tanah di seluruh wilayah Republik Indonesia menurut ketentuan-ketentuan yang diatur dengan peraturan pemerintah". Tujuan dari pendaftaran tanah itu secara lebih rinci disebutkan dalam Pasal 3 Peraturan Pemerintah Nomor 24 tahun 1997 tentang Pendaftaran Tanah yang menyatakan bahwa: 
1. Untuk memberikan kepastian hukum dan perlindungan hukum kepada pemegang hak atas suatu bidang tanah, satuan rumah susun dan hak-hak lain yang terdaftar agar dengan mudah dapat membuktikan dirinya sebagai pemegang hak yang bersangkutan.

2. Untuk menyediakan informasi kepada pihak-pihak yang berkepentingan termasuk Pemerintah agar dengan mudah dapat memperoleh data yang diperlukan dalam mengadakan perbuatan hukum mengenai bidang- bidang tanah dan satuan-satuan rumah susun yang sudah terdaftar.

3. Untuk terselenggaranya tertib administrasi pertanahan.

Pasal 4 ayat (1) Peraturan Pemerintah Nomor 24 tahun 1997 tentang Pendaftaran Tanah dinyatakan bahwa untuk memberikan kepastian dan perlindungan hukum sebagaimana dimaksud dalam Pasal 3 huruf (a) kepada pemegang hak yang bersangkutan diberikan sertifikat hak atas tanah". Dalam uraian pasal 4 Ayat (1) dapat diartikan bahwa dengan diterbitkannya sertifikat hak atas tanah, akan berguna sebagai alat bukti kepemilikan suatu hak atas tanah bagi pemegang hak atas tanah yang bersangkutan.

Sertifikat sebagai tanda bukti kepemilikan tanah di Indonesia bersifat kuat bukan mutlak. Pengertian sertifikat berasal dari bahasa Inggris “certificate” yang berarti ijazah atau Surat Keterangan yang dibuat oleh Pejabat tertentu. Dengan pemberian surat keterangan berarti Pejabat yang bersangkutan telah memberikan status tentang keadaan seseorang. Istilah "Sertifikat Tanah" dalam bahasa Indonesia diartikan sebagai surat keterangan tanda bukti pemegang hak atas tanah dan berlaku sebagai alat pembuktian yang kuat (http://blackvertical.blogspot.com/2012/06/pengertian-dan-fungsi-sertifikat-hak. diakses tanggal 30 maret 2015).

Sertifikat sendiri merupakan suatu hasil dari pendaftaran tanah yang merupakan kewajiban dari pemilik tanah. Menurut Boedi Harsono pengertian pendaftaran tanah sebagai suatu rangkaian kegiatan yang dilakukan secara teratur dan terus menerus untuk mengumpulkan, mengolah, menyimpan dan menyajikan data tertentu mengenai bidangbidang atau tanah-tanah tertentu yang ada di suatu wilayah tertentu dengan tujuan tertentu (Hasan Wargakusumah, 1995: 80).

Dalam perkembangannya, sertifikat mempunyai fungsi yang sangat tepat untuk kepastian hukum, yaitu (Adrian Sutedi, 2006:27-28) :

a. sertifikat hak atas tanah berfungsi sebagai alat pembuktian yang kuat. disebut dalam Pasal 19 ayat (2) huruf c UUPA. 
b. sertifikat hak atas tanah memberikan kepercayaan bagi pihak bank/kreditur untuk memberikan pinjaman uang kepada pemiliknya.

c. bagi pemerintah, Adanya sertifikat hak atas tanah membuktikan bahwa tanah yang bersangkutan telah terdaftar pada Kantor Agraria. Data tentang tanah yang bersangkutan secara lengkap telah tersimpan di Kantor Pertanahan, dan bila sewaktu-waktu diperlukan dengan mudah diketemukan.

Selain mempunyai fungsi diatas, sifat pembuktian sertifikat juga diatur dalam Pasal 32 ayat (1) dan (2) Peraturan Pemerintah Nomor 24 Tahun 1997 tentang Pendaftaran Tanah, yang menyatakan bahwa:

1. Sertifikat merupakan surat tanda bukti hak yang berlaku sebagai alat pembuktian yang kuat mengenai data fisik dan data yuridis yang termuat dalamnya, sepanjang data fisik dan data yuridis tersebut sesuai dengan data yang ada dalam surat ukur dan buku tanah hak yang bersangkutan.

2. Dalam hal atas suatu bidang tanah sudah diterbitkan sertifikat secara sah atas nama orang atau badan hukum yang memperoleh tanah tersebut dengan itikad baik dan secara nyata menguasainya, maka pihak lain yang merasa mempunyai hak atas tanah itu tidak dapat lagi menuntut pelaksanaan hak tersebut apabila dalam waktu 5 (lima) tahun sejak diterbitkannya sertifikat itu telah tidak mengajukan keberatan cara tertulis kepada pemegang sertifikat dan Kepala Kantor Pertanahan yang bersangkutan ataupun tidak mengajukan gugatan ke Pengadilan mengenai penguasaan tanah atau penerbitan sertifikat tersebut (Urip Santosa, $2010: .318$ ).

Dalam praktek jual beli tanah, terkadang ditemui suatu perjanjian jual beli yang ternyata tanahnya bersertifikat ganda. Dari uraian diatas, timbulnya sertifikat ganda disebabkan oleh dua hal, yaitu :

1. Kesalahan administrasi yang dilakukan oleh Kantor Badan Pertanahan Nasional, sehingga terbit dua sertifikat atau dua nama pemilik atas bidang tanah yang sama.

2. Ada unsur pemalsuan sertifikat aslinya, artinya sertifikatnya hanya satu tetapi oleh oknum atau orang yang tidak bertanggung jawab sertifikat tersebut digandakan atau dipalsukan sesuai atau mirip dengan aslinya.

Jadi sebutan atau istilah sertifikat ganda tersebut muncul dari dua hal tersebut, yang tentunya akan merugikan pembeli yang melakukan transaksi jual beli dengan itikad baik. 
Hukum diciptakan sebagai suatu sarana untuk mengatur hak dan kewajiban subjek hukum, agar subjek hukum dapat menjalankan kewajibannya dan mendapatkan haknya secara wajar. Selain itu fungsi hukum sebagai instrumen perlindungan bagi subjek hukum.

Dalam praktek pengembangan hukum di Indonesia, seringkali subyek hukum mengalami suatu hal yang seharusnya dia dilingungi oleh hukum tetapi karena keterbatasannya malah dia dirugikan oleh subyek hukum lain baik berupa penipuan ataupun perbuatan melawan hukum.

Oleh karena itu diperlukan suatu instrument dari pemerintah dalam rangka 'stuuren' atau pengendalian oleh pemerintah agar subyek hukum itu tidak dirugikan dan mendapat perlindungan hukum

Dalam teori perlindungan hukum, menurut Hadjon ada dua hal dalam perlindungan hukum, yaitu : Perlindungan hukum preventif dan perlindungan represif.

1) Perlindungan hukum yang preventif

Perlindungan hukum ini memberikan kesempatan kepada rakyat untuk mengajukan keberatan (inspraak) atas pendapatnya sebelum suatu keputusan pemerintahan mendapat bentuk yang definitif.

2) Perlindungan Hukum represif.

Perlindungan hukum represif merupakan perlindungan akhir berupa sanksi seperti denda, penjara, dan hukuman tambahan yang diberikan apabila sudah terjadi sengketa atau telah dilakukan suatu pelanggaran (Philipus M.Hadjon, 1987: 2-5) .

Sedangkan konsep Itikad Baik menurut Imran yaitu itikad baik terbagi menjadi dua macam, yakni itikad baik nisbi dan itikad baik mutlak Pada itikad yang pertama, seseorang memperhatikan sikap dan tingkah laku yang nyata dari subjek. Pada itikad yang kedua, penilaian terletak pada akal sehat dan keadilan serta dibuat ukuran yang obyektif untuk menilai keadaan (penilaian tidak memihak) menurut norma-norma yang objektif (S. Imran, 2007).

\section{B. Analisis Faktor-Faktor Penyebab Terjadinya Sertifikat Ganda Di Indonesia.}

Undang-Undang Nomor 5 Tahun 1960 tentang Peraturan Dasar Pokok Pokok Agraria yang diundangkan pada tanggal 24 September 1960, yang dikenal dengan UUPA, merupakan pelaksanaan Pasal 33 ayat (3) Undang-Undang Dasar Negara Republik 
Indonesia Tahun 1945. Sebelum berlakunya UUPA, hanya bagi tanah-tanah yang tunduk kepada hukum Barat, misalnya Hak Eigendom, Hak Erpacht, Hak Opstal, dilakukan pendaftaran tanah yang tujuannya untuk memberikan jaminan kepastian hukum dan kepada pemegangnya diberikan tanda bukti dengan suatu akta yang dibuat oleh Pejabat Balik Nama (Adrian Sutedi, 2007: 112).

Menurut Peraturan Pemerintah Nomor 24 tahun 1997 bahwa kepastian hukum mengenai hak-hak atas tanah sebagaimana yang diamanatkan UUPA mengandung dua dimensi yaitu kepastian obyek hak atas tanah dan kepastian subyek hak atas tanah. Salah satu indikasi kepastian obyek hak atas tanah ditunjukkan oleh kepastian letak bidang tanah yang berkoordinat geo-referensi dalam suatu peta pendaftaran tanah, sedangkan kepastian subyek diindikasikan dari nama pemegang hak atas tanah tercantum dalam buku pendaftaran tanah pada instansi pertanahan. Secara ringkas, salinan dari peta dan buku pendafataran tanah tersebut dikenal dengan sebutan Sertifikat Tanah.

Sertifikat hak atas tanah sebagai hasil akhir proses pendaftaran hak atas tanah termasuk perubahan-perubahan menyangkut subyeknya, status haknya dan perbuatanperbuatan hukum yang dilakukan terhadap tanahnya merupakan alat pembuktian yang kuat sebagaimana dinyatakan dalam ketentuan Pasal 19 ayat (1) huruf c, Pasal 23 ayat (2), Pasal 32 ayat (2) dan Pasal 38 ayat (2) UUPA. Sertifikat merupakan tanda bukti yang kuat dan bukan merupakan tanda bukti yang mutlak/sempurna menurut ketentuan UUPA dan Peraturan Pemerintah yang melaksanakannya (Peraturan Pemerintah Nomor 10 Tahun 1961 dan Peraturan Pemerintah Nomor 24 Tahun 1997).

Hal ini berarti bahwa keterangan-keterangan yang tercantum di dalamnya mempunyai kekuatan hukum dan harus diterima (oleh hakim) sebagai keterangan yang benar selama dan sepanjang tidak ada alat pembuktian yang membuktikan sebaliknya (Arie S. Hutagalung, 2005: 81). Dalam Pasal 32 ayat (1) Peraturan Pemerintah Nomor 24 Tahun 1997 disebutkan bahwa sertifikat merupakan tanda bukti hak yang berlaku sebagai alat pembuktian yang kuat, namun pada ayat (2) pasal tersebut menyebutkan apabila diatas suatu bidang tanah yang sudah diterbitkan sertifikat secara sah atas nama orang atau badan hukum yang memperoleh tanah tersebut dengan itikad baik dan secara nyata menguasainya, maka pihak lain yang merasa mempunyai hak atas tanah itu tidak lagi dapat menuntut pelaksanaan hak tersebut apabila dalam waktu 5 (lima) tahun sejak diterbitkannya sertifikat itu tidak mangajukan keberatan secara tertulis kepada pemegang 
sertifikat dan Kepala Kantor Pertanahan yang bersangkutan ataupun tidak mengajukan gugatan ke Pengadilan mengenai penguasaan tanah atau penerbitan sertifikat.

Dari ketentuan tersebut diatas, masih sangat terbuka kemungkinan adanya gangguan dari pihak yang merasa mempunyai hak atas tanah tersebut atau merasa dirugikan dengan mengajukan keberatan kepada Kantor Pertanahan setempat dan kepada pemegang sertifikat hak atas tanah tersebut apabila penerbitan sertifikat hak atas tanah belum 5 (lima) tahun. Salah satu fenomena permasalahan dalam konteks hukum pertanahan nasional adalah seringnya muncul sertifikat ganda (bahkan ada yang lebih dari dua) yang berdasarkan rumusan pasal 32 ayat (2) Peraturan Pemerintah Nomor 24 Tahun 1997 tentang Pengadaan Tanah dapat mengakibatkan kerugian kepada pembeli tanah yang beritikad baik.

Dalam hal penerbitan sertifikat secara jelas juga sudah diatur dalam Peraturan Pemerintah Nomor 24 Tahun 1997 tentang Pengadaan Tanah dalam Pasal 31 disebutkan bahwa sertifikat diterbitkan untuk kepentingan pemegang hak yang bersangkutan sesuai dengan data fisik dan data yuridis yang telah didaftar dalam buku tanah. Jika di dalam buku tanah terdapat catatan yang menyangkut data yuridis, atau catatan yang menyangkut data fisik maupun data yuridis penerbitan sertifikat ditangguhkan sampai catatan yang bersangkutan dihapus. Sertifikat hanya boleh diserahkan kepada pihak yang namanya tercantum dalam buku tanah yang bersangkutan sebagai pemegang hak atau kepada pihak lain yang dikuasakan olehnya. Mengenai hak atas tanah atau hak milik atas satuan rumah susun kepunyaan bersama beberapa orang atau badan hukum diterbitkan satu sertifikat yang diterimakan kepada salah satu pemegang hak bersama atas penunjukan tertulis para pemegang hak bersama yang lain. Sedangkan mengenai hak atas tanah atau hak milik atas satuan rumah susun kepunyaan bersama dapat diterbitkan sertifikat sebanyak jumlah pemegang hak bersama untuk diberikan kepada tiap pemegang hak bersama yang bersangkutan, yang memuat nama serta besarnya bagian masing-masing dari hak bersama tersebut. Di samping itu bentuk, isi, cara pengisian dan penandatanganan sertifikat ditetapkan oleh Menteri.

Keberadaan sertifikat ganda yang sampai saat ini masih menjadi permasalahan dan belum dapat diselesaikan dikarenakan ada beberapa faktor-faktor hukum maupun non hukum. Dari sisi teori dan pendapat para pakar faktor-faktor penyebab terjadinya sertifikat ganda adalah sebagai berikut : 
1) Sertifikat ganda dapat terjadi karena beberapa kekeliruan teknis sebagai berikut:

a. Pada waktu dilakukan pengukuran ataupun penelitian di lapangan, pemohon dengan sengaja atau tidak sengaja menunjukkan letak tanah dan batas-batas tanah yang salah.

b. Adanya surat bukti atau pengakuan hak dibelakang hari terbukti mengandung ketidakbenaran, kepalsuan atau sudah tidak berlaku lagi.

c. Untuk wilayah yang bersangkutan belum tersedia peta pendaftaran tanahnya.

d. Kasus penerbitan lebih dari satu sertifikat atas sebidang tanah dapat pula terjadi atas tanah warisan. Latar belakang kasus tersebut adalah sengketa harta warisan yaitu oleh pemilik sebelum meninggalnya telah dijual kepada pihak lain tanpa diketahui oleh anak-anaknya dan telah diterbitkan sertifikat atas nama pembeli, dan kemudian para ahli warisnya mensertifikatkan tanah yang sama, sehingga mengakibatkan terjadi sertifikat ganda, karena sertifikat terdahulu ternyata belum dipetakan.

2) Terjadinya sertifikat ganda merupakan salah satu akibat adanya tumpang tindih dalam penerbitan sertifikat hak atas tanah yang disebut cacat hukum administrasi. Sebagaimana terdapat dalam Pasal 107 Peraturan Menteri Agraria/ Kepala Badan Pertanahan Nasional Nomor 9 Tahun 1999 Tentang Tata Cara Pemberian dan Pembatalan Hak Atas Tanah dan Hak Pengelolaan, sertifikat hak atas tanah yang cacat hukum administratif adalah sertifikat hak atas tanah yang mengandung kesalahan antara lain sebagai berikut:
a) kesalahan prosedur
b) kesalahan penerapan peraturan perundang-undangan
c) kesalahan subjek hak
d) kesalahan objek hak
e) kesalahan jenis hak
f) kesalahan perhitungan luas
g) terdapat tumpang tindih hak atas tanah
h) data yuridis dan data fisik tidak benar; atau
i) kesalahan lainnya yang bersifat administratif

3) Terjadinya sertifikat ganda dipengaruhi oleh adanya faktor intern dan faktor ekstern (Utoyo Sutopo, 1992: 5), Faktor-faktor tersebut dilihat dari dalam instansi Kantor Pertanahan. Faktor-faktor intern yang dimaksud adalah: 
1. Tidak dilaksanakannya UUPA dan peraturan-peraturan pelaksanaannya secara konsekuen dan bertanggungjawab disamping masih adanya orang yang berbuat untuk memperoleh keuntungan pribadi. Faktor-faktor tersebut dilihat dari dalam instansi Kantor Pertanahan.

2. Kurang berfungsinya aparat pengawas sehingga memberikan peluang kepada aparat bawahannya untuk bertindak menyeleweng dalam arti tidak melaksanakan tugas dan tanggungjawab sesuai sumpah jabatannya.

3. Ketidak-telitian pejabat Kantor Pertanahan dalam menerbitkan sertifikat tanah yaitu dokumen-dokumen yang menjadi dasar bagi penerbitan sertifikat tidak diteliti dengan seksama yang mungkin saja dokumen-dokumen tersebut belum memenuhi persyaratan sebagaimana ditentukan oleh ketentuan-ketentuan perundang -undangan yang berlaku.

4. Kantor Pertanahan selaku Instansi Pemerintah dalam membuat dan menerbitkan sertifikat tanah sangat tergantung pada data yang diterbitkan oleh instansi pemerintah lainnya seperti pemerintahan daerah/desa dan kantor pelayanan pajak.

Sedangkan faktor-faktor ekstern yang dimaksud adalah:

1. Masyarakat masih kurang mengetahui dan memahami undang-undang dan peraturan pelaksanaan tentang pertanahan khususnya mengenai prosedur pembuatan sertifikat tanah.

2. Persediaan tanah yang tidak seimbang dengan jumlah peminat yang memerlukan tanah dan ekonomi masyarakatnya itu sendiri.

3. Pembangunan mengakibatkan kebutuhan akan tanah semakin meningkat sedangkan persediaan tanah terbatas sehingga mendorong peralihan fungsi tanah pertanian ke tanah non pertanian, mengakibatkan harga tanah terus melonjak tinggi.

Sehingga berdasarkan faktor-faktor munculnya sertifikat ganda tersebut memungkinkan adanya bentuk dari sertifikat ganda adalah :

1) Kedua atau lebih sertifikat nya asli tapi salah satunya asli tapi palsu. Artinya keduanya mempunyai salinan/arsip di Kantor Pertanahan Kabupaten/Kota. Hal ini dapat terjadi karena suatu bidang tanah yang sudah bersertifikat didaftarkan 
lagi pada Kantor Pertanahan, jadi keduanya memang asli produk BPN akan tetapi obyek/bidang tanahnya sama baik letak, posisi maupun luasnya.

2) Kedua sertifikat palsu, artinya kedua sertifikat tersebut tidak terdapat salinannya di Kantor Pertanahan/BPN atau tidak ada arsipnya

3) Salah satu atau lebih sertifikat tersebut merupakan bagian dari sertifikat yang lain. Hal ini terjadi karena bidang tanah yang didaftarkan seharusnya didaftarkan melalui proses pemecahan sertifikat induknya, atau sebaliknya penerbitan sertifikat yang satu harusnya merupakan penggabungan dari beberapa sertifikat yang lain.

4) Overlapping (tumpang tindih) yaitu ada dua atau lebih sertifikat yang tumpang tindih satu dengan lainnya sehingga bagian yang tumpang tindih tersebut merupakan sertifikat ganda, karena sebagian tanahnya termasuk dalam sertifikat yang lain. Adapun gaambaran terkait dengan Overlapping sebagai berikut :

a) Tumpang tindih seluruhnya

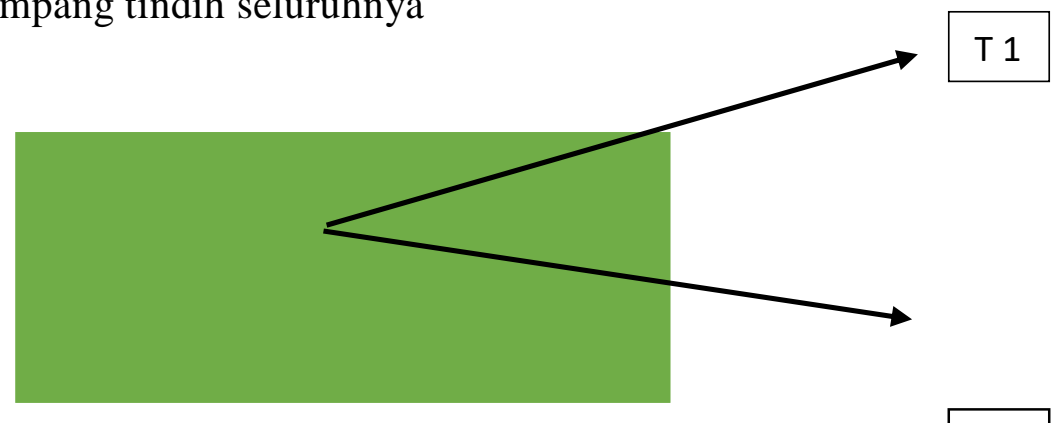

b) Tumpang Tindih Sebagian

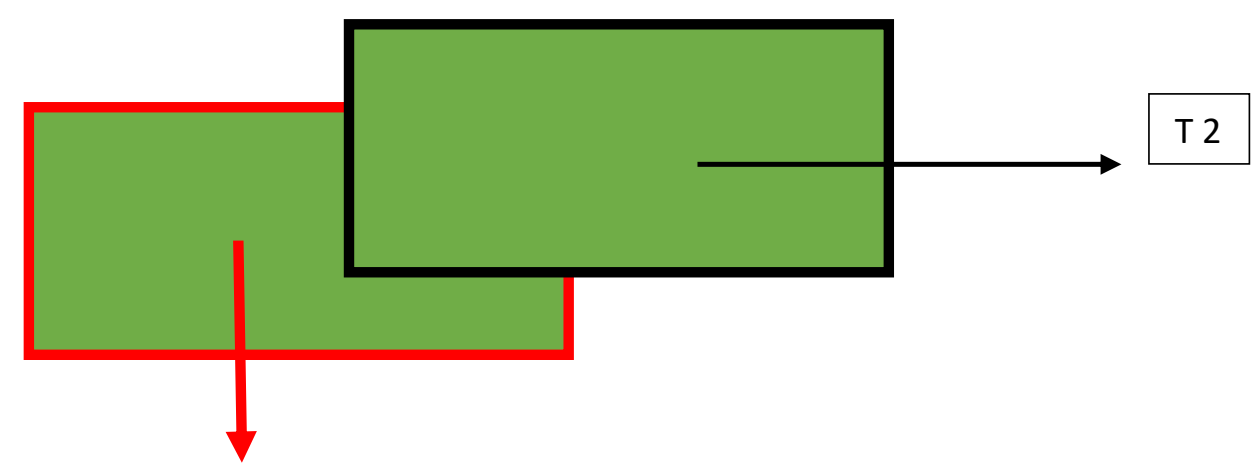


c) Tumpang Tindih Seluruhnya

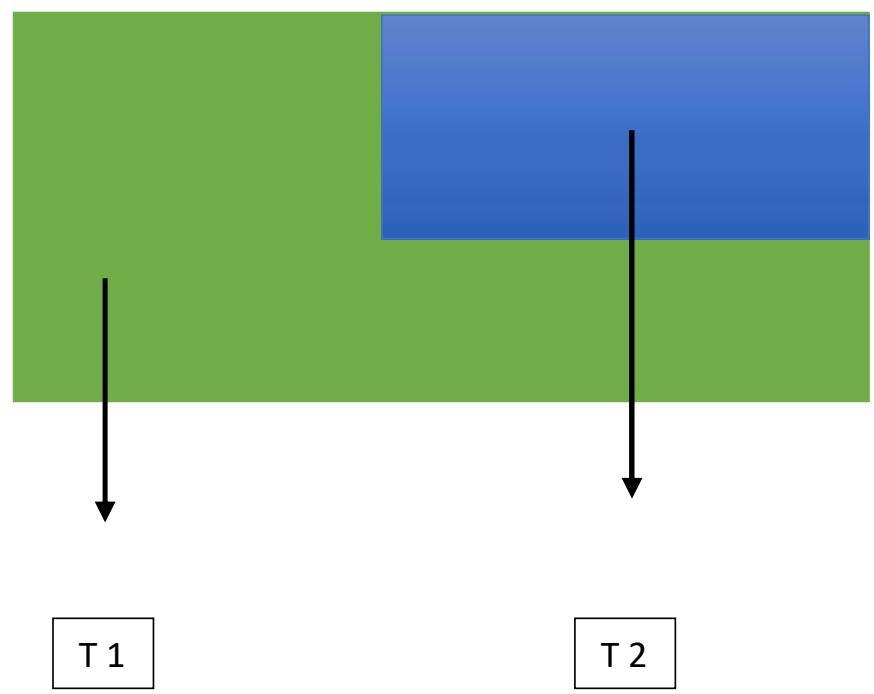

\section{Perlindungan Hukum Terhadap Pembeli Yang Beritikad Baik Tetapi Ternyata Tanahnya Bersertifikat Ganda}

Bentuk perlindungan hukum dapat dianalisis melalui teori yang dikemukakan oleh Philipus M. Hadjon, yaitu perlindungan hukum terbagi menjadi 2 yakni perlindungan hukum preventif dan represif.

Dalam perlindungan hukum preventif kepada rakyat diberikan kesempatan untuk mengajukan keberatan atau pendapatnya sebelum suatu keputusan pemerintah mendapat bentuk yang definitif dan pada perlindungan hukum represif dilakukan upaya untuk menyelesaikan sengketa yang sudah terjadi.

Dalam perlindungan preventif, perlindungan diberikan oleh pemerintah dalam hal ini adalah BPN dengan tujuan untuk mencegah sebelum terjadinya pelanggaran yakni dengan dikeluarkannya UUPA dan Peraturan Pemerintah tentang pendaftaran tanah serta peraturan lainnya yang mengatur mengenai pendaftaran tanah, sehingga dengan dikeluarkannya aturan mengenai pendaftaran tanah dapat mewujudkan tujuan dari pendaftaran tanah itu sendiri. 
Pengertian jual beli menurut KUHPerdata adalah suatu perjanjian timbal balik, dimana pihak penjual berjanji untuk menyerahkan Hak Milik atas suatu barang dan pihak pembeli berjanji untuk mebayar harga yang terdiri atas sejumlah uang sebagai imbalan perolehan barang dari pihak penjual (R. Subekti, Bandung: 1). Menurut Pasal 1457 KUHPerdata jual beli tanah adalah suatu persetujuan dengan mana pihak yang satu mengikatkan dirinya untuk menyerahkan suatu kebendaan dan pihak yang lain untuk membayar harga yang diperjanjikan.

Jika jual belinya mengenai tanah maka atas tanah baru beralih kepada pembelinya jika telah dilakukan penyerahan yuridis. Penyerahan yuridis dilakukan dengan pembuatan akta dimuka dan oleh Kepala Kantor Pertanahan selaku Pejabat Balik Nama, berdasarkan ketentuan Overschrijving Ordonantie (Stb.1834 No.27). Dan menurut Pasal 1458 KUHPerdata jual beli dan penyerahan hak kepada pembeli merupakan 2 (dua) perbuatan yang berlainan. Selama masih belum diakukan penyerahan yuridis tanah masih merupakan milik penjual meskipun sudah dikuasai pembeli.

Pada saat ini dalam jual beli tanah sudah tidak dikenal lagi istilah pengertian balik nama, karena sudah diganti dengan ketentuan Pendaftaran Tanah yang diatur oleh Peraturan Pemerintah Nomor 10 Tahun 1961 dan telah diganti /disempurnakan dengan Peraturan Pemerintah Nomor 24 Tahun 1997 tentang Pendaftaran Tanah. Menurut ketentuan KUHPerdata untuk jual beli hal atas tanah pengaturannya termasuk dalam Hukum Perjanjian mengenai jual belinya, sedangkan mengenai penyerahan yuridisnya termasuk dalam Hukum Agraria. Adapun ketentuan yang berkaitan dengan tanah sebagaimana diatur dalam Buku II KUHPerdata telah dihapuskan dan tidak berlaku lagi, dan diatur dalam Undang-Undang Nomor 5 Tahun 1960 beserta peraturan-peraturan pelaksanaannya.

Penerbitan sertifikat diberikan kepada yang berhak, bertujuan agar pemegang hak dapat dengan mudah membuktikan kepemilikan tanahnya. Peraturan Pemerintah Nomor 24 Tahun 1997 dalam Pasal 5 secara tegas menyebutkan bahwa instansi Pemerintah yang menyelenggarakan pendaftaran tanah di seluruh wilayah Republik Indonesia adalah Badan Pertanahan Nasional (BPN). Selanjutnya dalam Pasal 6 ayat (1) ditegaskan bahwa dalam rangka penyelenggaraan pendaftaran tanah tersebut, tugas pelaksanaan pendaftaran tanah dilakukan oleh Kepala Kantor Pertanahan Kabupaten/Kota. Dalam pelaksanaannya walaupun pendaftaran tanah sudah dilakukan, namun masih sering terjadi sengketa- 
sengketa hak-hak atas tanah di tengah-tengah masyarakat yang bahkan seringkali sampai pada gugatan-gugatan ke pangadilan, yang mengakibatkan terjadinya pemblokiran ataupun bahkan pembatalan sertifikat hak atas tanah tersebut oleh Kantor Pertanahan. Hal ini dapat mengakibatkan pihak-pihak yang memperoleh tanah, yang walaupun telah mengikuti prosedur yang sesuai, menjadi sangat dirugikan.

Mekanisme penanganan sengketa hak atas tanah (sertifikat ganda) diselenggarakan penyelesaiannya melalui Instansi Badan Pertanahan Nasional (BPN) dan melalui pengadilan.

1) Melalui Badan Pertanahan Nasional (BPN)

a) Pengaduan/Keberatan dari masyarakat.

Suatu sengketa hak atas tanah itu timbul adalah karena adanya pengaduan/keberatan dari orang / Badan Hukum yang berisi kebenaran dan tuntutan terhadap suatu Keputusan Tata Usaha Negara di bidang pertanahan yang telah ditetapkan oleh Pejabat Tata Usaha Negara di lingkungan Badan Pertanahan Nasional, dimana keputusan Pejabat tersebut dirasakan merugikan hak-hak mereka atas suatu bidang tanah tertentu. Dengan adanya pengaduan tersebut, mereka ingin mendapat penyelesaian secara administrasi dengan apa yang disebut koreksi serta merta dari Pejabat yang berwenang untuk itu. Bahwa kewenangan untuk melakukan koreksi terhadap suatu keputusan Tata Usaha Negara di bidang pertanahan (sertifikat / Surat Keputusan Pemberian Hak Atas Tanah), hanya ada pada Kepala Badan Pertanahan Nasional. Adapun sengketa hak atas tanah adalah meliputi beberapa macam antara lain mengenai status tanah, siapa-siapa yang berhak, bantahan terhadap bukti-bukti perolehan yang menjadi dasar pemberian hak atau pendaftaran dalam buku tanah dan sebagainya.

b) Penelitian dan pengumpulan data.

Setelah menerima berkas pengaduan dari masyarakat tersebut diatas, pejabat yang berwenang mengadakan penelitian terhadap data / administrasi maupun hasil di lapangan / fisik mengenai penguasaannya sehingga dapat disimpulkan pengaduan tersebut beralasan atau tidak untuk diproses lebih lanjut.

c) Pencegahan mutasi (penetapan status quo).

Agar kepentingan orang atau Badan Hukum yang berhak atas tanah yang disengketakan tersebut mendapat perlindungan hukum, maka apabila dipandang 
perlu setelah Kepala Kantor Pertanahan setempat mengadakan penelitian dan apabila dari keyakinannya memang harus distatus-quokan, dapat dilakukan pemblokiran atas tanah sengketa.

d) Pelayanan secara musyawarah.

Terhadap sengketa hak atas tanah yang disampaikan kepada BPN untuk dimintakan penyelesaian, apabila pihak-pihak yang bersengketa dapat dipertemukan dapat dilakukan penyelesaiannya melalui cara musyawarah dan BPN seringkali diminta sebagai mediator dalam menyelesaikan sengketa secara damai dan saling menghormati diantara pihak-pihak yang bersengketa.

e) Pencabutan/pembatalan Surat Keputusan Tata Usaha Negara dibidang Pertanahan oleh Kepala BPN berdasarkan adanya cacat hukum/administrasi di dalam penerbitannya.

Dalam praktek selama ini banyak sekali orang/Badan Hukum yang merasa kepentingannya dirugikan mengajukan keberatan tersebut langsung kepada Kepala BPN. Demikian juga permohonan pembatalan sertifikat hak atas tanah yang didasarkan adanya Putusan Pengadilan yang telah berkekuatan tetap. Yang menjadi dasar kewenangan tersebut adalah:

1) Undang-Undang Nomor 5 Tahun 1960 tentang Peraturan Dasar Pokok-pokok Agraria.

2) Peraturan Pemerintah Nomor 24 Tahun 1997 tentang Pendaftaran Tanah.

3) Keputusan Presiden Nomor 26 Tahun 1988 tentang Pembentukan Badan Pertanahan Nasional.

4) Peraturan Menteri Negara Agraria/Kepala BPN Nomor 3 Tahun 1999.

2) Penyelesaian sengketa hak atas tanah melalui pengadilan

a) Apabila penyelesaian melaui musyawarah diantara para pihak tidak tercapai, demikian pula apabila penyelesaian secara sepihak dari Kepala BPN karena mengadakan Peninjauan Kembali atas Keputusan Tata Usaha Negara yang telah dikeluarkannya tida dapat diterima oleh pihak-pihak yang bersengketa, maka penyelesaiannya harus melalui Pengadilan.

b) Sampai adanya putusan yang berkekuatan hukum tetap, dilarang bagi Pejabat Tata Usaha Negara terkait untuk mengadakan mutasi atas tanah yang bersangkutan. Hal ini untuk menghindari terjadinya masalah dikemudian hari 
yang menimbulkan kerugian bagi pihak-pihak yang berperkara, maupun pihak ketiga.

c) Sambil menunggu adanya putusan yang telah mempunyai kekuatan hukum tetap (in kracht van geweijsde), surat-surat tanda bukti yang diberikan berupa sertifikat hak atas tanah dikatakan sebagai alat pembuktian yang kuat, hal ini berarti bahwa keterangan-keterangan yang tercantum dalam sertifikat mempunyai kekuatan hukum dan harus diterima sebagai keterangan yang benar oleh hakim selama tidak dapat dibuktikan sebaliknya oleh pihak lain. Apabila pihak lain dapat membuktikan sebaliknya maka yang berwenang memutuskan alat pembuktian mana yang benar adalah pengadilan.

d) Kemudian apabila sudah ada putusan hakim yang mempunyai kekuatan hukum yang tetap, maka Kepala Kantor Pertanahan Kabupaten/Kotamadya setempat melalui Kepala Kantor Wilayah BPN Propinsi yang bersangkutan mengusulkan permohonan pembatalan/pencabutan suatu Keputusan Tata Usaha Negara dibidang Pertanahan yang telah diputuskan tersebut di atas. Permohonan tersebut harus dilengkapi dengan laporan mengenai semua data-data yang menyangkut subyek dan beban-beban yang ada di atas tanah tersebut serta segala permasalahan yang ada.

\section{Simpulan}

Penyebab terjadinya sertifikat ganda bisa dikarenakan adanya unsur kesengajaan, ketidaksengajaan dan dikarenakan kesalahan administrasi baik secara internal maupun eksternal. Bentuk perlindungan hukum terhadap pembeli beritikad baik tetapi tanahnya bersertifikat ganda dapat melakukan pengaduan kepada Badan Pertanahan Nasional dilakukan dengan proses mediasi yang merupakan proses penyelesaian berdasarkan prinsip win-win solution yang diharapkan mampu memberikan penyelesaian secara memuaskan dan diterima oleh semua pihak. Apabila penyelesaian tidak juga tercapai, maka kepada pihak penggugat dipersilahkan mengajukan gugatan melalui Pengadilan Negeri setempat dengan tenggat waktu 90 hari sesuai dengan ketentuan yang berlaku (Peraturan Pemerintah Nomor 24 tahun 1997).

Badan Pertanahan Nasional sebaiknya melakukan pembaharuan dalam proses penerbitan sertifikat, dimana sebaiknya pendaftaran sertifikat dilakukan secara Online, sehingga kemungkinan untuk timbulnya sertifikat ganda sangat kecil. Karena dengan sistem ini, pengecekan atas suatu hak dapat dilakukan dengan cepat. Perlu diciptakan 
lembaga Pengadilan Agraria yang pada saat ini merupakan kebutuhan mutlak serta merupakan mekanisme jalan keluar dari sejumlah sengketa agrarian agar proses peradilan dapat berjalan dengan baik, tepat dan cepat sehingga tidak ada konflik kompetensi peradilan antara Peradilan Tata Usaha Negara dengan Peradilan Umum ataupun konflik kompetensi tentang pemeriksaan lembaga peradilan yang mana yang harus didahulukan

\section{Daftar Pustaka:}

Hadjon, Philipus M dan Tatiek Sri Djatmiati. 2005. Argumentasi Hukum. Yogyakarta: Gajah Mada University Press.

Hadjon, Philipus M.. 1987. Perlindungan Hukum Bagi Rakyat di Indonesia. Surabaya: Bina Ilmu.

Hardiyanto, Andik. 1998. Agenda Land Reform Di Indonesia Sekarang. Bandung: Konsorsium Pembaruan Agraria (KPA) Bekerja sama dengan INPI - Pact.

Harsono, Boedi. 2003. Hukum Agraria Indonesia (Sejarah Pembentukan UUPA, Isi dan Pelaksanaanya). Jakarta: Djambatan.

Hutagalung, Arie Sukanti. 1985. Program Redistribusi Tanah di Indonesia. Jakarta: Rajawali.

Parlindungan, A.P.. 1991. Komentar Atas UUPA. Bandung: Mandar Maju.

Peter Butt, Land Law (Third Edition), 1996. The Law Book Company limited. New South Wales.

Santosa, Urip. 2010. Hukum Agraria \& Hak-Hak Atas Tanah. Jakarta: Prenada Media Group.

Sutedi, Adrian. 2006. Kekuatan Hukum Berlakunya Sertifikat sebagai Tanda Bukti Hak Atas Tanah. Jakarta: BP.Cipta Jaya,.

Wargakusumah, Hasan. 1995. Hukum Agraria I, Jakarta: Gramedia Pustaka Utama. 